\title{
RANCANG BANGUN SISTEM INFORMASI LAYANAN ELEKTRONIK PROGRAM STUDI TEKNIK INFORMATIKA FAKULTAS TEKNIK UNIVERSITAS MATARAM
}

\author{
(Design of Information System Electronic Service in Programming Study Informatics \\ Engineering Faculty of Engineering Mataram University)
}

\author{
Baiq Nia Rahmawati", I Wayan Agus Arimbawa, Ahmad Zafrullah Mardiansyah \\ Dept Informatics Engineering, Mataram University \\ JI. Majapahit 62, Mataram, Lombok NTB, INDONESIA \\ Email: Baiqniar@gmail.com, Arimbawa@unram.ac.id, Zafrullah@unram.ac.id
}

\begin{abstract}
The design of the PSTI Electronic Service Information System, Faculty of Engineering, University of Mataram is an advanced system that supports the correspondence process that is asked by students to ask for permission, such as research permit, submission of supporting data for the final assignment, submission of data for coursework, submission to college transfer, invite leave and be active again. This system works to make outgoing letters needed by students for submitting applications requested for this form above or processed by other parties as to the Admin Study Staff Program. The test results with the black box method all functions are by following the system proposed and expected by system users, especially students and admins. Based on the results of testing the Mean Opinion Score method, it can be concluded that $64 \%$ of respondents agreed and $36 \%$ of respondents stated that they strongly agreed with the design of electronic service information systems, informatics engineering study programs, engineering faculty, Mataram University.
\end{abstract}

Keywords: system, information, electronic, service, letters.

*Penulis Korespondensi

\section{Pendahuluan}

Teknologi informasi saat ini semakin berkembang dengan pesat, sehingga menyebabkan segala aspek kehidupan manusia selalu dihubungkan dengan perkembangan teknologi tersebut. Pengaruh dari perkembangan teknologi tersebut bisa dirasakan berbagai bidang baik dari bidang akademik maupun non-akademik. Manfaat yang bisa dirasakan dari perkembangan teknologi yaitu pengolahan data yang bisa dilakukan secara tepat, cepat, dan akurat. Dengan bantuan teknologi informasi, segala proses pengolahan data dalam sistem bisa dilakukan di berbagai tempat yang berbeda sehingga bisa lebih efektif dan efisien.

Pengolahan data yang dilakukan secara manual sudah mulai ditinggalkan dan diubah menjadi sistem yang terkomputerisasi untuk memudahkan proses pengolahan data sehingga bisa dilakukan dengan cepat dan tidak membutuhkan waktu yang cukup lama. Selain itu, pengolahan dan pengaksesan data yang masih menggunakan sistem manual yang dapat menghambat kinerja dari suatu instansi atau

perusahaan.

Pada Program Studi Teknik Informatika Universitas Mataram khususnya di bagian layanan surat menyurat, yang dibutuhkan oleh mahasiswa sudah ada bagian form pengajuan permohonan surat tersendiri untuk pengurusannya. Namun form pengajuan permohonan ini pengisiannya masih belum terancang dengan kompleks, masih membutuhkan perkembangan agar form pengajuan permohonan ini pengisiannya dapat lebih kompleks dari pengisian sebelumnya. Form pengajuan permohonan surat ini pengisiannya masih ditulis secara manual tidak menggunakan komputer. Yang diharapkan dari form pengajuan permohonan ini pengisian suratnya dapat dilakukan melalui komputer sepenuhnya, tidak lagi menggunakan sistem secara manual.

Penerapan sistem informasi yang terkomputerisasi juga akan meningkatkan kinerja sesuai sasaran atau kriteria yang diinginkan. Oleh karena itu, pada penelitian tugas akhir ini akan dilakukan penelitian tentang "Rancang Bangun Sistem Informasi Layanan Elektronik Program Studi Teknik Informatika Fakultas Teknik Universitas Mataram". Sistem ini adalah 
sebuah sistem lanjutan dari sistem yang sebelumnya yaitu, layanan surat keluar yang di butuhkan oleh mahasiswa untuk form permohonan izin, seperti: form pengajuan permohonan izin penelitian, form pengajuan data pendukung untuk tugas akhir, form pengajuan data untuk tugas kuliah, form pengajuan pindah kuliah, form permohonan cuti dan aktif kembali. pengisian form pada surat keterangan ini hanya mencakup 5 jenis surat, karena ini memiliki proses yang sama dan hasil keluarannya hanya di tujukan kepada ketua program studi untuk di sahkan. Setelah surat di keluarkan oleh ketua program studi baru mahasiswa dapat mengambil surat. Hal ini di lakukan agar dapat mempermudah mahasiswa untuk melakukan pengisian surat.

\section{TINJAUAN Pustaka}

Penelitian yang telah mengimplementasikan sistem informasi pengelolaan surat dan kearsipan "Sistem Kearsipan Surat Masuk dan Keluar di Kantor Kepala Desa Tridadi Kecamatan Sleman Kabupaten Sleman Berbasis Visual Basic" [1]. Pada perancangan sistem informasi kearsipan di kantor kepala desa tridaddi, penulis menggunakan desain model dalam bentuk physical system (flowchart) dan Logical model (data flow diagram). Sistem Informasi Kearsipan Surat Keluar dan Surat Masuk berbasis visual basic ini dapat mempermudah pencarian data pencatatan surat masuk dan surat keluar, serta pengklasifikasiannya sehingga memudahkan dalam temu balik arsip, serta nantinya dapat membantu dalam pembuatan laporan terhadap atasan.

Penelitian lainnya yang telah mengimplementasikan sistem informasi pengelolaan surat dan kearsipan "Perancangan Sistem Informasi Arsip Surat Menyurat Di Universitas U'Budiyah Indonesia Menggunakan Php dan MySql" [2]. Pada perancangan sistem informasi kearsipan di Universitas U'Budiyah Indonesia, penulis menggunakan desain model dalam bentuk physical system (flowchart) dan Entity Relation Diagram (ERD). Dengan adanya sistem informasi arsip surat menyurat ini, mahasiswa dapat melakukan proses permintaan pembuatan surat melalui aplikasi kepada pihak akademik tanpa harus mendatangi pihak akademik langsung.

Selain itu sistem informasi pengelolaan surat dan kearsipan pada "Perancangan Sistem Informasi Administrasi Surat Masuk dan Surat Keluar Di Kecamatan Ketapang Kabupaten Bandung" [3]. Pada perancangan sistem informasi administrasi surat masuk dan keluar di kecamatan ketapang kabupaten bandung ini, penulis menggunakan desain model dalam bentuk Entity Relation Diagram (ERD) dan logical model (data flow diagram). Sistem informasi administrasi surat masuk dan surat keluar di Kecamatan Ketapang Kabupaten Bandung telah diimplementasikan dengan hasil memudahkan dalam pencarian surat masuk dan surat keluar serta dokumentasi yang lebih tertata rapi.

Penelitian mengenai sistem informasi surat yaitu penelitian "Rancang Bangun Sistem Informasi Surat Universitas Islam Negeri Sunan Kalijaga Menggunakan Pendekatan Agile Process dengan Model Extreme Programming" [4]. Pada perancangan sistem, penulis menggunakan desain model dalam bentuk use case diagram, entity relation diagram, class diagram, sequence diagram dan activity diagram. Pada penelitian ini bertujuan untuk merancang dan membangun sistem informasi surat secara terpusat yang dapat memudahkan pegawai dalam proses administrasi persuratan.

Sistem informasi tentang surat-menyurat juga pernah di implementasikan pada penelitian "Rancang Bangun Sistem Informasi Manajemen Surat" [5] . Semua proses keluar masuk surat dicatat dalam sebuah buku besar. Proses surat masuk dibagi menjadi dua, yaitu surat pribadi dan surat dinas. Surat pribadi akan langsung disampaikan kepada pemiliknya. Sedangkan surat dinas akan diperiksa oleh bagian tala usaha. Setelah itu, maka surat akan diteruskan untuk kemudian diberi disposisi. Untuk Surat keluar setelah diparaf oleh bagian yang berwenang dan ditandatangani, akan dicatat dalam buku besar kemudian surat dapat dikirimkan. Hal ini tidak menutup kemungkinan akan hilangnya beberapa buah surat. Hal ini juga akan menghambat usaha pencarian sebuah data. Dalam proses pemberian surat tugas, dilakukan penghitungan jumlah surat tugas untuk masing-masing personal. Untuk mengatasi hal tersebut, dibuatlah sebuah sistem administrasi manajemen surat dengan menggunakan bahasa pemrograman Delphi 6 dengan database menggunakan MySQL.

\section{Metode Peneltian}

\subsection{Alat dan Bahan}

Pada penelitian ini, akan dibangun sebuah Rancang Bangun Sistem Informasi Layanan Elektronik pada Program Studi Teknik Informatika Fakultas Teknik Universitas Mataram.

Adapun alat dan bahan yang diperlukan dalam penelitian tugas akhir ini dikelompokkan menjadi 2 yaitu perangkat keras dan perangkat lunak. Berikut 
adalah informasi detail spesifikasi perangkat keras dan perangkat lunak yang digunakan.

\subsubsection{Perangkat Keras}

Perangkat keras yang digunakan pada penelitian tugas akhir ini adalah Laptop Asus X44C Series dengan spesifikasi (Intel(R) Celeron(R) CPU B800 @ 1.50GHz 1.50G Hz) RAM 2 GB, 320GB Harddisk, OS Windows 7 ultimate 32-bit.

\subsubsection{Perangkat Lunak}

Perangkat lunak yang digunakan dalam penelitian ini adalah:

a. Microsoft Office

b. Microsoft Visio 2013

c. Sublime Text Editor

d. WAMP server / XAMPP server

e. Framework PHP Laravel.

\subsubsection{Bahan}

Data yang diperlukan terdiri dari:

a. Data Mahasiswa yang masih aktif kuliah.

b. Surat keluar untuk pengajuan permohonan.

\subsection{Proses Penelitian}

Untuk menjawab rumusan masalah dan tujuan akhir dari penelitian ini, penulis melakukan tahapan demi tahapan yang diuraikan dalam diagram alir penelitian penelitian. Berikut adalah diagram alir yang memperlihatkan tahapan-tahapan yang dilakukan dalam penelitian tugas akhir ini.

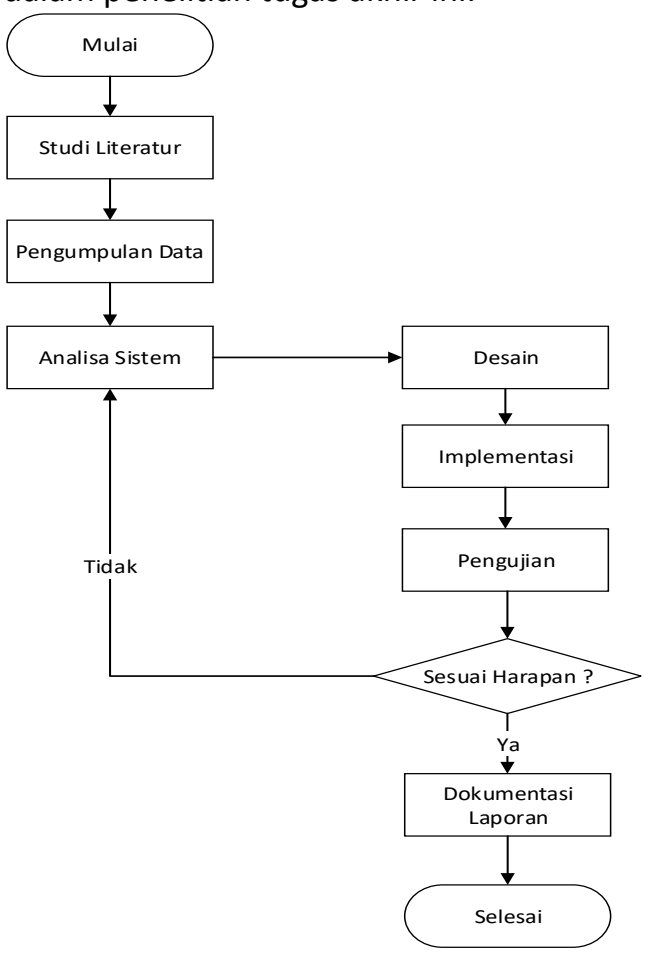

Gambar 1. Diagram alir penelitian

\subsubsection{Studi Literatur}

Studi literatur dilakukan dengan mempelajari dan memahami literatur yang berkaitan dengan penelitian. Studi literatur yang digunakan untuk membantu penulisan tugas akhir ini [6]. Studi literatur mempelajari hal-hal yang terkait dengan pengembangan sistem menggunakan metode waterfall serta mempelajari perancangan sistem informasi pengelolaan surat, framework Laravel dan yang digunakan dalam membangun sistem.

\subsubsection{Pengumpulan Data}

Pada tahap pengumpulan data dilakukan studi kasus pada program studi teknik informatika fakultas teknik universitas mataram dengan berapa metode diantaranya:

\section{Metode wawancara}

Pada metode wawancara dilakukan wawancara kepada staff dan dosen bagian program studi teknik informatika untuk mendapatkan informasi mengenai sistem pengelolaan surat dan yang digunakan saat ini dan informasi mengenai sistem yang diharapkan. Proses wawancara bertujuan untuk mendapatkan data-data yang dibutuhkan dalam membangun sistem informasi pengelolaan surat berupa data surat keluar dan data mahasiswa aktif[7].

\section{Metode observasi}

Pada metode observasi dilakukan peninjauan secara langsung pada staff dan dosen bagian program studi teknik informatika fakultas teknik universitas mataram untuk mengetahui proses sistem yang sedang berjalan.

\subsubsection{Analisis Sistem}

Analisa sistem merupakan tahapan paling awal dari pengembangan sistem yang menjadi pondasi dalam menentukan keberhasilan sistem informasi yang dihasilkan nantinya. Tahapan ini sangat penting karena menentukan bentuk sistem yang akan dibangun[8].

\section{A. Analisis Sistem yang berjalan}

Secara umum sistem yang sedang berjalan di Program Studi Teknik Informatika Fakultas Teknik Universitas Mataram yaitu sebagai berikut:

1. Sistem yang sedang berjalan.

Sistem informasi surat yang sedang berjalan pada Program Studi Teknik Informatika Fakultas Teknik Universitas Mataram yang ditunjukan pada Gambar 2. 


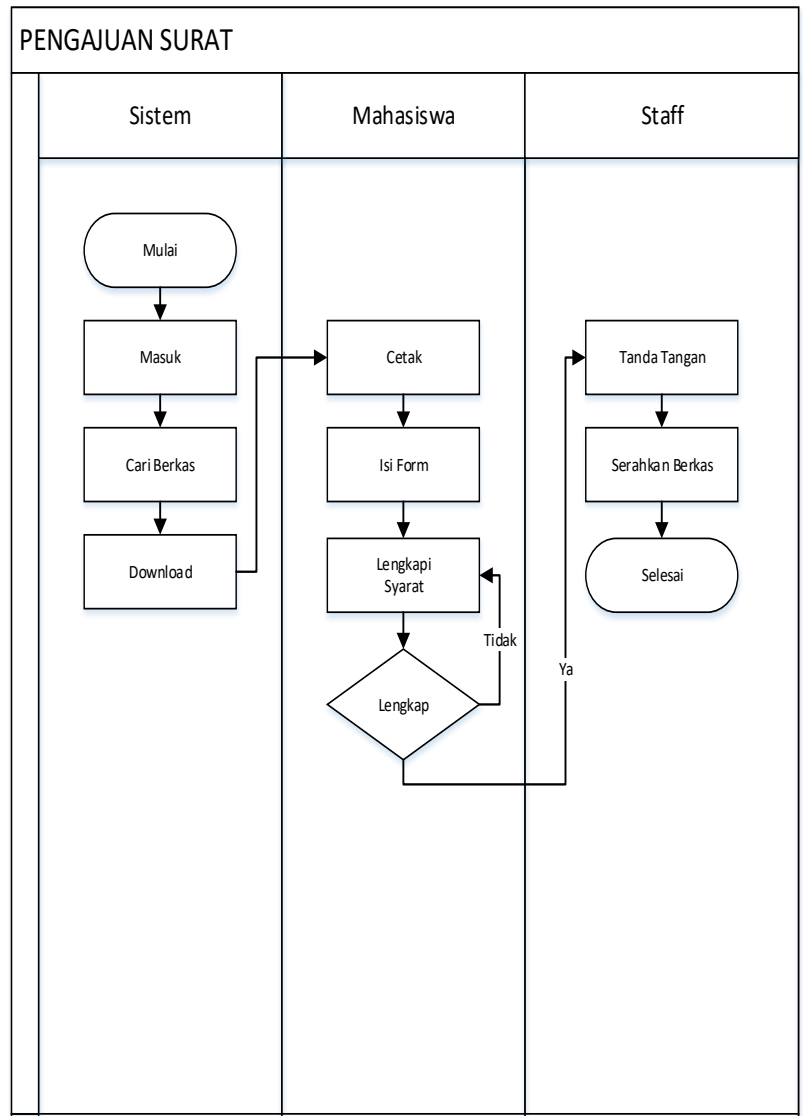

Gambar 2. Sistem yang sedang berjalan.

\section{B. Analisis Sistem Usulan}

Pada analisa sistem yang di usulkan sistem yang akan dibangun yaitu hampir sama dengan sistem sebelumnya, hanya saja sistem sebelumnya masih manual sedangkan sistem yang di usulkan dapat lebih kompleks dari sebelumnya.

1. Sistem informasi surat keluar yang diusulkan pada Program Studi Teknik Informatika Fakultas Teknik Universitas Mataram dari sisi Mahasiswa pada Gambar 3.

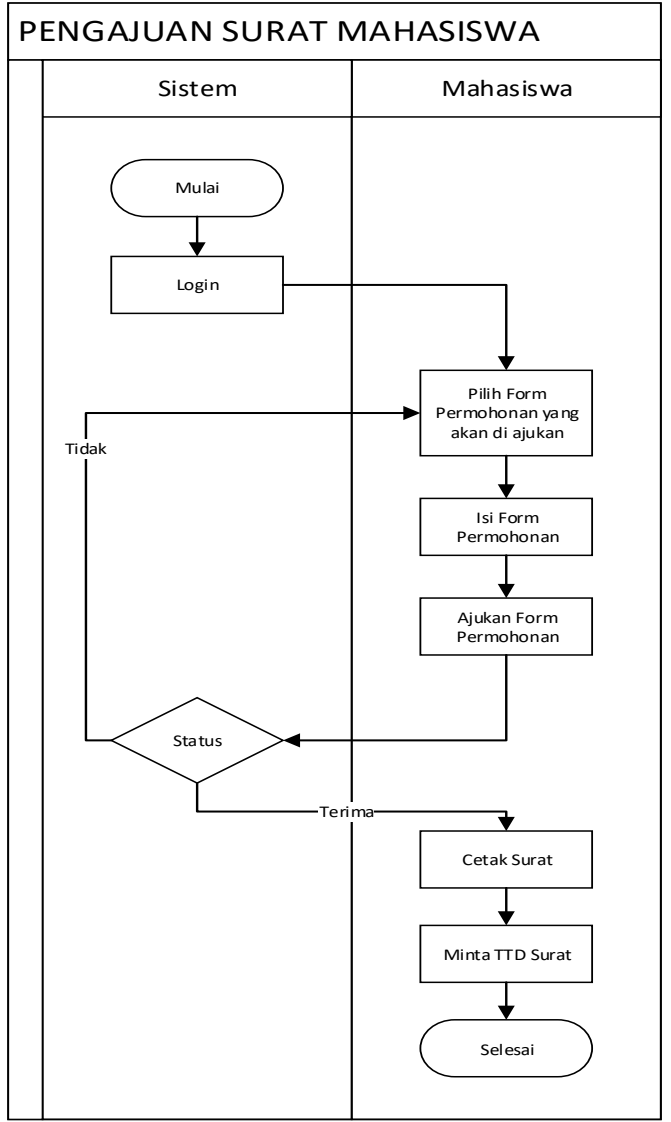

Gambar 3. Sistem yang diusulkan dari sisi Mahasiswa

2. Sistem informasi surat keluar yang diusulkan pada Program Studi Teknik Informatika Fakultas Teknik Universitas Mataram dari sisi Admin pada Gambar 4.

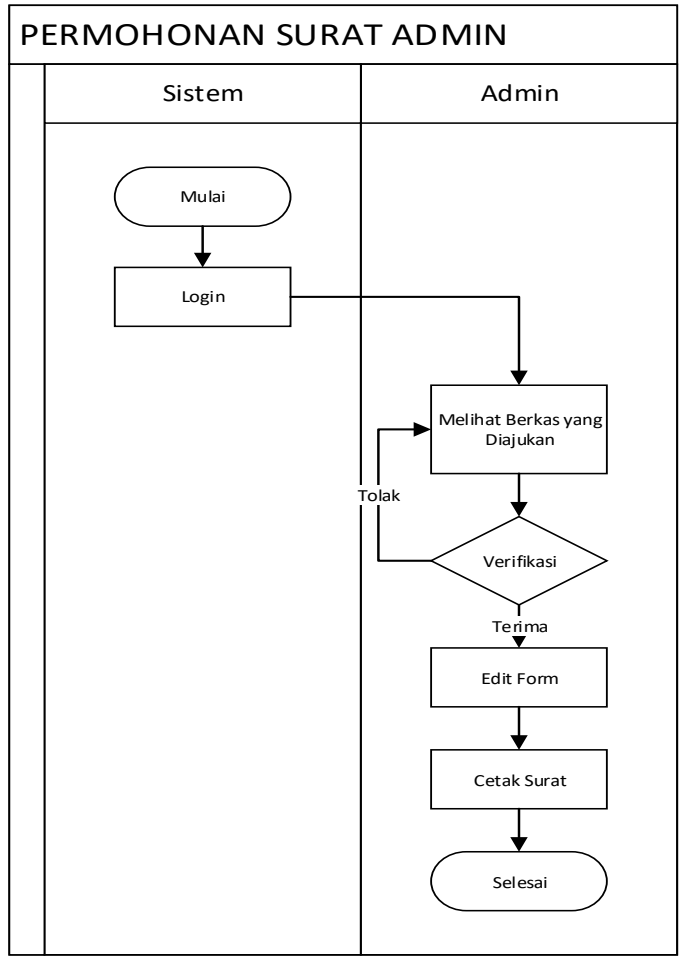

Gambar 4. Sistem yang diusulkan dari sisi Admin 


\section{Analisis Kebutuhan Sistem}

Analisa kebutuhan dari suatu sistem membutuhkan data masukan (input), proses yang dilakukan oleh sistem mulai dari awal hingga mendapatkan output atau keluaran, sehingga dapat direpresentasikan dalam pemodelan UML (Unified Modeling Language). Tahapan pemodelan dalam analisis UML antara lain pembuatan use case diagram, entity relation diagram, class diagram, sequence diagram dan activity diagram.

\subsubsection{Perancangan (Design)}

Tahap design merupakan tahap perancangan atau penggambaran suatu sistem yang akan dikembangkan. Pada sistem informasi surat ini menggunakan Unified Modeling Langauage (UML). Bentuk UML yang digunakan dalam perancangan sistem adalah use case diagram, entity relation diagram, class diagram, sequence diagram dan activity diagram[9]. Berikut merupakan perancangan sistem informasi surat keluar:

\section{A. Use Case Diagram}

Use case diagram sistem informasi layanan elektronik program studi teknik informatika fakultas teknik universitas mataram digunakan untuk menjelaskan kegiatan dari masing-masing aktor yang terlibat dalam sistem informasi yang akan di kembangkan. Aktor yang terlibat dalam sistem layanan elektronik ini ada 2 yaitu, aktor mahasiswa dan admin. Yang memiliki pekerjaan masing-masing sebagai aktor. Seperti pada aktor mahasiswa disini yang bisa di lakukan yaitu, pertama mahasiswa dapat login ke sistem, kemudian mahasiswa dapat mengajukan surat yang diinginkan, setelah pengajuan surat mahasiswa dapat mengecek status surat sudah terverifikasi atau belum, setelah di verifikasi oleh admin mahasiswa tinggal mencetak surat kemudian minta tanda tangan pada dosen pembimbing yang bersangkutan. Sedangkan dari aktor admin yang dapat dilakukan yaitu, pertama aktor dapat melihat mahasiswa yang mengajukan surat dan surat apa saja yang diajukan, setelah itu admin dapat memverifikasi surat dan mengirim pesan verifikasi pada mahasiswa, disini juga admin dapat mengedit, menghapus serta menolak surat pengajuan dari mahasiswa jika terjadi kesalahan, admin juga menginputkan dosen pembimbing yang menjadi dosen pembimbing tugas akhir, karena data dosen pembimbing tugas akhir belum ada pada sistem akademik unram. Use case diagram sistem informasi layanan elektonik ini dapat dilihat pada Gambar 5.

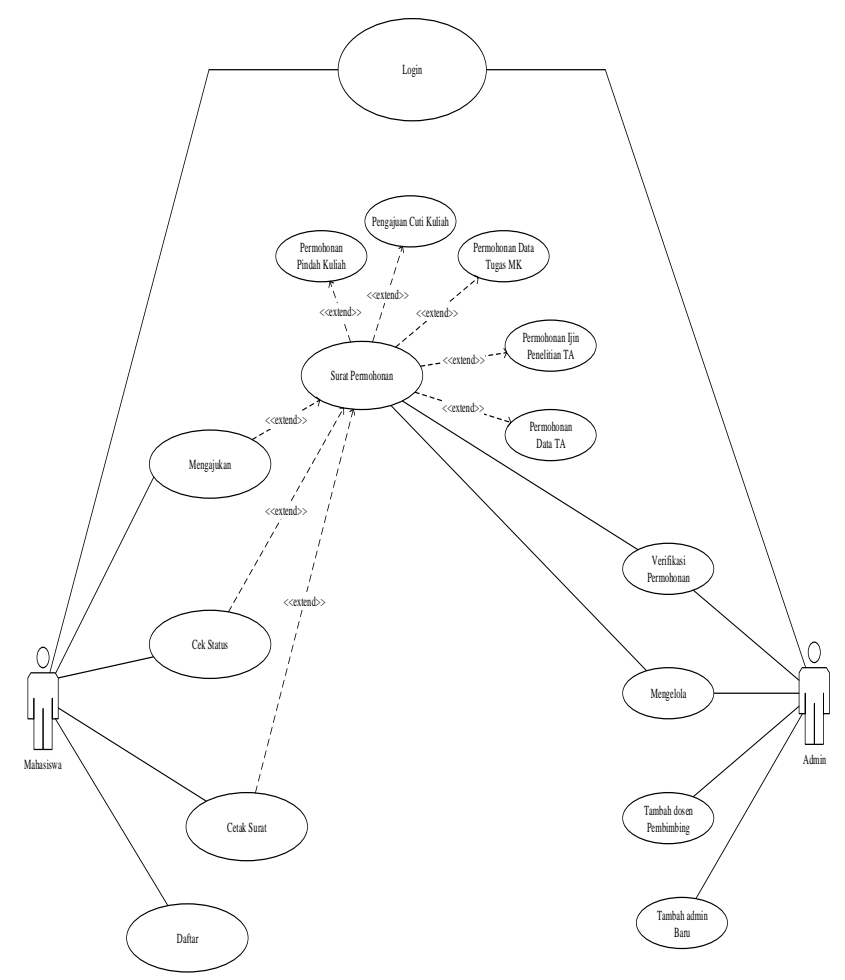

Gambar 5. Use Case Diagram

\section{B. Entity Relationship Diagram (ERD)}

Entity Relationship Diagram(ERD) sistem informasi layanan elektronik untuk mendukung surat keluar memiliki beberapa entitas, relasi dan atribut. ERD ini menjelaskan tentang alur yang di lakukan sistem informasi ini, diantaranya dapat mengajukan permohonan surat yaitu permohonan surat pindah, cuti dan aktif, data pendukung tugas mata kuliah, data pendukung tugas akhir dan ijin penelitian tugas akhir, yang di ajukan oleh mahasiswa kepada admin yang merupakan staff prodi. Admin melakukan pengecekan terhadap surat yang di ajukan oleh setiap mahasiswa, kemudian admin dapat memverifikasi surat dan menyerahkan kembali kepada mahasiswa. Mahasiswa dapat mengecek apakah surat yang di ajukan sudah di verifikasi atau belum melalui status yang di berikan oleh pihak admin, setelah status diverifikasi mahasiswa dapat mencetak surat permohonan. Perancangan ERD sistem informasi layanan elektronik dapat dilihat pada Gambar 6. 


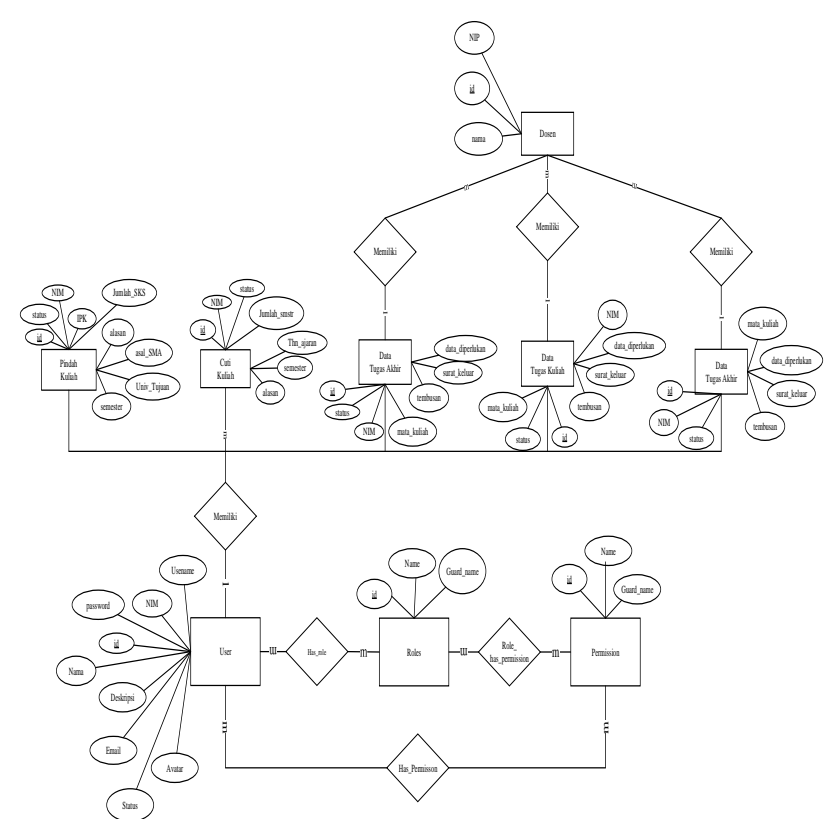

Gambar 6. ER Diagram

\section{4. hasil dan Pembahasan}

\subsection{Implementasi Sistem}

Pada sistem layanan elektronik program studi teknik terdapat proses-proses yang di lakukan untuk mengakses surat yang di inginkan oleh mahasiswa. Adapun penjelasan dari beberapa proses yang dilakukan adalah sebagai berikut:

\section{Form Login}

Sistem ini menyediakan halaman untuk login. Form login yaitu suatu interface yang digunakan untuk masuk kedalam sistem yang dituju, proses ini dilakukan agar tidak sembarangan orang dapat masuk ke dalam suatu sistem. Pada saat mahasiswa atau admin melakukan login diperlukan data-data seperti username/email dan password. Jika ada mahasiswa yang baru ingin masuk pada sistem disediakan form daftar atau register.
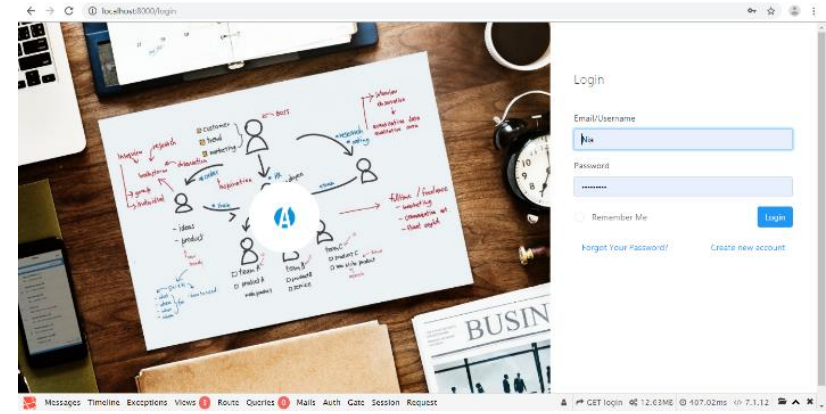

Gambar 7. Form Login

\section{Form Beranda Mahasiswa}

Sistem ini menyediakan halaman untuk beranda mahasiswa, dimana halaman beranda ini digunakan mahasiswa untuk memproses surat yang diinginkan, pada saat mahasiswa login, mahasiswa langsung di arahkan ke halaman ini, halaman ini berisi fitur permohonan cuti, pindah kuliah, permohonan data tugas akhir, permohonan data tugas kuliah, permohonan izin penelitian skripsi, dan pada halaman ini juga ada fitur pesan yaitu untuk melihat surat persetujuan apa saja yang telah diverifikasi oleh admin, setelah diverifikasi admin dapat mencetak surat persetujuan tersebut .

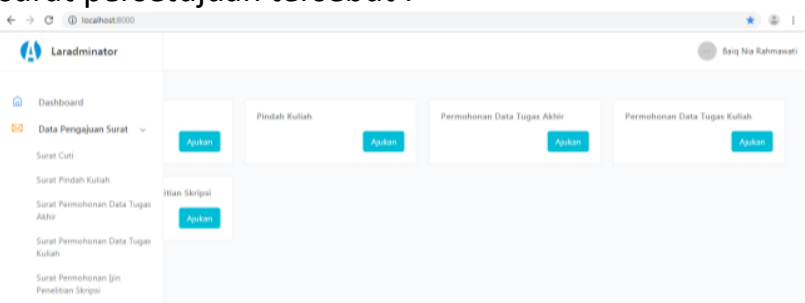

\section{Gambar 8. Form Beranda Mahasiswa}

\section{Form Beranda Admin}

Sistem ini menyediakan halaman untuk admin, dimana pada halaman ini digunakan untuk melihat pengajuan surat yang diajukan oleh mahasiswa, memverifikasi surat, menambah dosen yang menjadi dosen pembimbing tugas akhir, dan untuk menambah user yang ingin masuk pada sistem dapat sebagai mahasiswa admin atau staff.

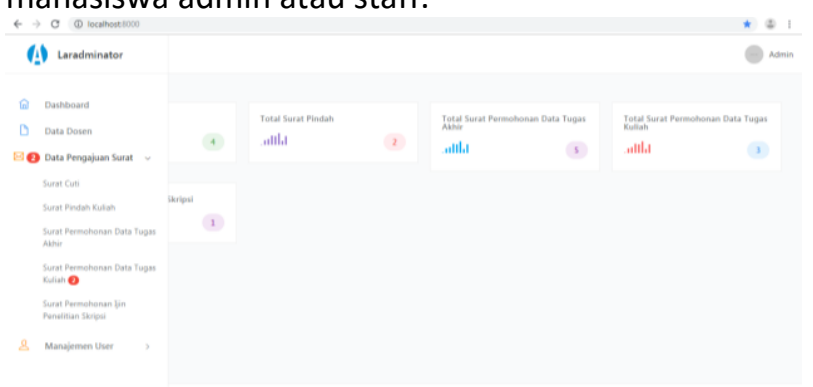

Gambar 9. Form Beranda Admin

\section{Form Tambah Dosen}

Sistem ini menyediakan halaman untuk menambah dosen yang menjadi dosen pembimbing tugas akhir, form tambah dosen di isikan oleh sistem sendiri karena pada SIA tidak menyediakan data dosen yang menjadi dosen pembimbing. 


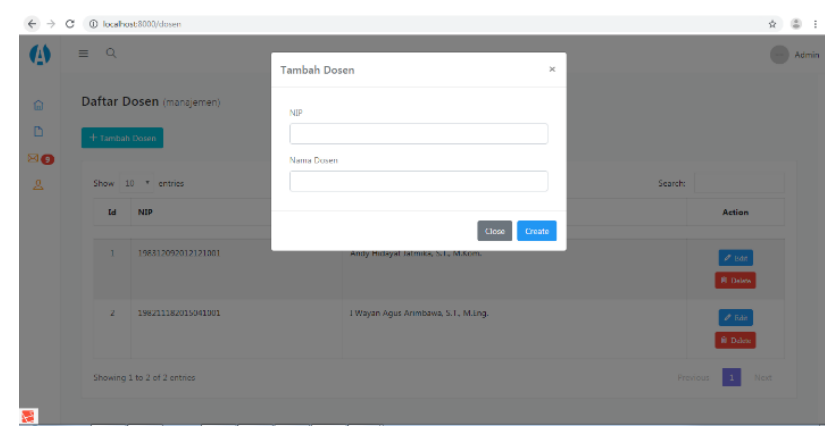

Gambar 10. Form Tambah Dosen

\section{Form Data Dosen}

Sistem ini menyediakan halaman data dosen yang telah ditambah menjadi dosen pembimbing.

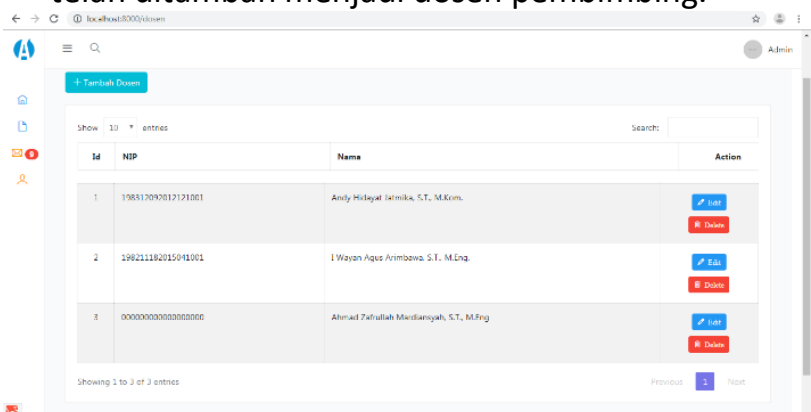

Gambar 11. Form Data Dosen

\section{Form Pengajuan Surat Cuti oleh Mahasiswa}

Sistem ini menyediakan halaman untuk pengajuan cuti mahasiswa, dimana halaman ini mahasiswa mengirimkan form yang telah diisikan untuk memproses surat cuti, data yang isikan hanya data yang tidak ada pada SIA.

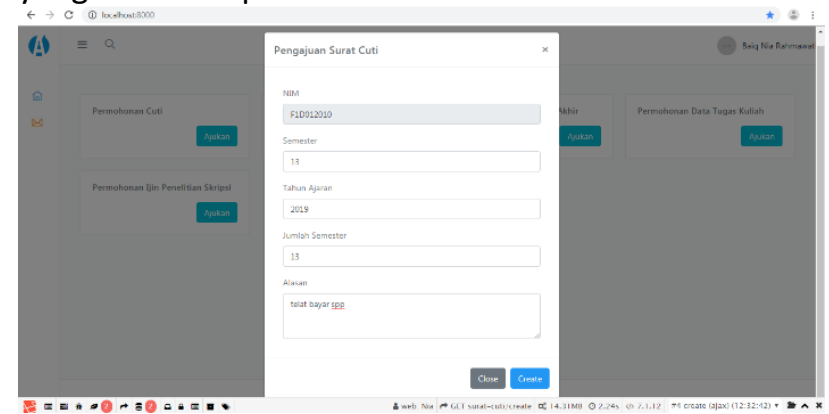

Gambar 12. Form pengajuan cuti oleh mahasiswa

7. Form Data mahasiswa yang mengajukan cuti disisi Admin

Sistem ini menyediakan data mahasiswa yang telah mengajukan surat cuti. Data yang telah diisikan oleh admin kemudian diverifikasi setelah itu dikirimkan pesan kemahasiswa bahwa surat yang diajukan telah diverifikasi kemudian mahasiswa dapat unduh surat permohonan. Pada sistem ini admin juga dapat mengunduh surat, mengedit atau menghapus.

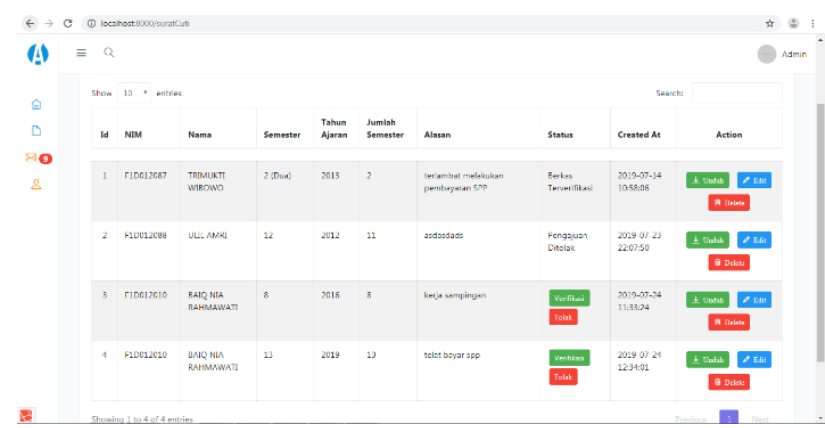

Gambar 13. Form Data mahasiswa yang mengajukan cuti disisi Admin

\section{Form data pengajuan cuti disisi mahasiswa}

Sistem ini menyediakan data pengajuan cuti yang telah diisikan oleh mahasiswa sebelumnya. Setelah mahasiswa mengirimkan pengajuan, admin memverifikasi setelah itu diterima lagi sebagai pesan oleh mahasiswa dan surat permohonan dapat diunduh untuk dicetak.

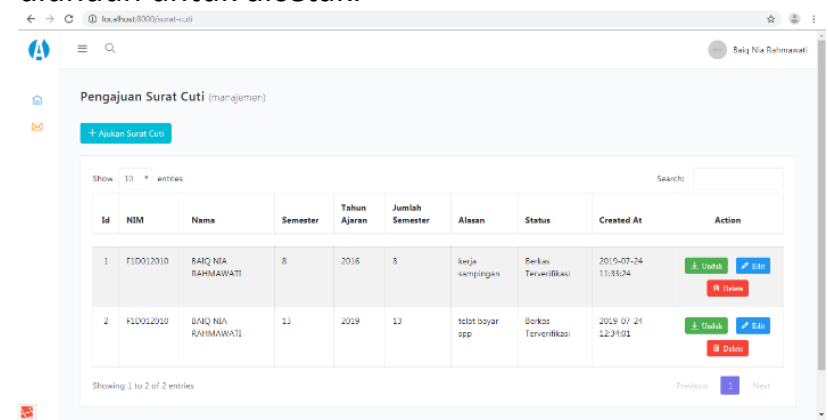

Gambar 14. Form Data pengajuan cuti disisi mahasiswa

\section{Form tambah user}

Sistem ini menyediakan form untuk menambah user baik sebagai admin, mahasiswa ataupun staff untuk dapat login pada sistem. Disini hanya admin yang memiliki fitur tambah user.

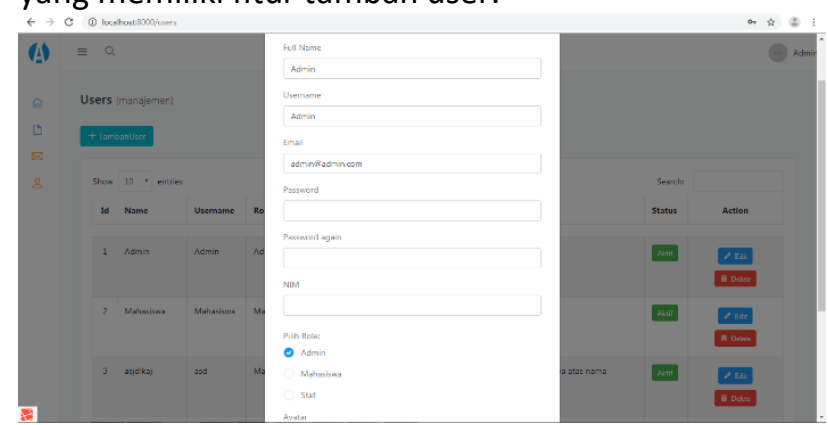

Gambar 15. Form tambah user

\section{Form User yang Telah Login}

Sistem ini menyediakan data users yang telah login ke dalam sistem baik admin, mahasiswa ataupun staff. 3 user yang ada pada sistem ini memiliki hak 
akses masing-masing pada sistem. Mahasiswa hanya dapat mengajukan permohonan surat dan mendaftar saja, admin dan staff dapat mengelola akun, namun staff tidak dapat membuat user baru kedalam sistem. Akun yang telah login ke dalam sistem adalah akun yang aktif dan nantinya akun dapat diedit atau dihapus jika ada kesalahan dan jika sudah berganti akun.

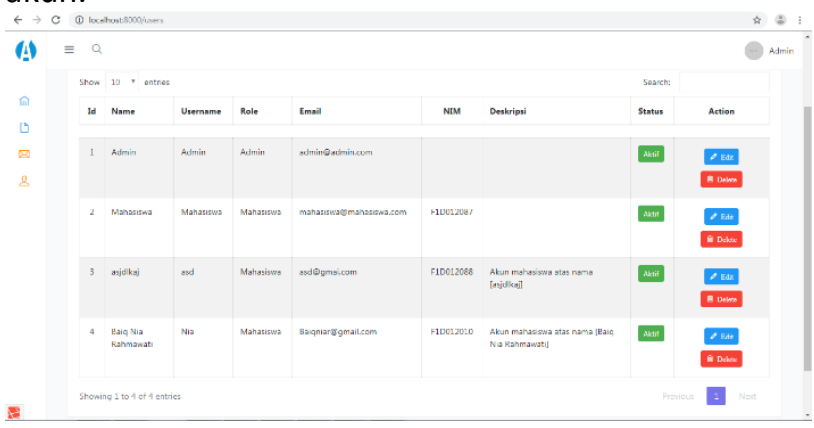

Gambar 16. Form User yang Telah Login

\subsection{Hasil Pengujian Kuesioner dengan Metode Mean Opinion Score (MOS).}

Metode Mean Opinion Score (MOS) merupakan suatu penilaian kualitatif terhadap hasil citra. Penilaian ini berdasarkan pada pengamatan mata manusia, sehingga baik buruknya hasil segmentasi ini bergantung pada penilaian subjektif masingmasing koresponden.

Kuesioner pengujian sistem terdiri dari 5 pernyataan, yaitu:

1. Desain interface(tampilan)dari sistem ini cukup menarik.

2. Hasil yang ditampilkan sesuai keinginan (output sistem valid).

3. Sistem ini dapat membantu setiap mahasiswa untuk melakukan permohonan surat.

4. Sistem ini dapat mempermudah admin untuk melakukan pengisian surat.

5. Sistem ini dapat digunakan pada program studi teknik informatika fakultas teknik universitas mataram.

Dari pernyataan tersebut, responden diminta untuk menjawab dengan nilai-nilai tertentu, diantaranya:

1. 1 = Sangat tidak setuju.

2. 2 = Tidak setuju.

3. $3=$ Setuju.

4. 4 = Sangat setuju.

Berdasarkan jawaban tersebut, langkah selanjutnya adalah menghitung persentase dari setiap jawaban yang diberikan oleh pengguna di setiap pertanyaan.

Berdasarkan data hasil kuisioner, dapat dicari persentase masing-masing jawaban dengan menggunakan persamaan (1)[10][11].

$$
Y=\frac{P}{Q} * 100 \%
$$

Dimana : $\mathrm{P}=$ Banyaknya jawaban tiap pertanyaan

$$
\begin{aligned}
& Q=\text { Jumlah responden } \\
& Y=\text { Nilai persentasi }
\end{aligned}
$$

Untuk menghitung persentase rata-rata nilai dari setiap poin jawaban, perhitungan digunakan perhitungan seperti pada persamaan (4-2) sebagai berikut.

Rata - rata $=$

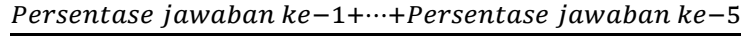

Hasil rekapitulasi data kuisioner dan persentase jawaban pengguna pada setiap pertanyaan yang telah dihitung dengan menggunakan Persamaan (1) dan (2) disajikan pada Tabel I.

TABel I. Hasil Pengujian Kuesioner Dari Sistem

\begin{tabular}{|c|c|c|c|c|}
\hline \multicolumn{1}{|c|}{ Pernyataan } & $\begin{array}{c}\text { Sangat } \\
\text { Tidak } \\
\text { Setuju }\end{array}$ & $\begin{array}{c}\text { Tidak } \\
\text { Setuju }\end{array}$ & Setuju & $\begin{array}{c}\text { Sangat } \\
\text { Setuju }\end{array}$ \\
\hline $\begin{array}{l}\text { Desain interface(tampilan) dari sistem ini } \\
\text { cukup menarik }\end{array}$ & 0 & 0 & 20 & 5 \\
\hline $\begin{array}{l}\text { Hasil yang ditampilkan sesuai } \\
\text { keinginan(output sistem valid) }\end{array}$ & 0 & 0 & 14 & 11 \\
\hline $\begin{array}{l}\text { Sistem ini dapat membantu setiap mahasiswa } \\
\text { untuk melakukan permohonan surat }\end{array}$ & 0 & 0 & 15 & 10 \\
\hline $\begin{array}{l}\text { Sistem ini dapat mempermudah admin untuk } \\
\text { melakukan pengisian surat }\end{array}$ & 0 & 0 & 15 & 10 \\
\hline $\begin{array}{l}\text { Sistem ini dapat digunakan pada program } \\
\text { studi teknik informatika fakultas teknik } \\
\text { universitas mataram }\end{array}$ & 0 & 0 & 16 & 9 \\
\hline Total & $\mathbf{0}$ & $\mathbf{0}$ & $\mathbf{8 0}$ & $\mathbf{4 5}$ \\
\hline Rata-Rata & $\mathbf{0}$ & $\mathbf{0}$ & $\mathbf{1 6}$ & $\mathbf{9}$ \\
\hline Rata-Rata(\%) & $\mathbf{0}$ & $\mathbf{0}$ & $\mathbf{6 4 \%}$ & $\mathbf{3 6 \%}$ \\
\hline
\end{tabular}

Berdasaran hasil pengujian kuisioner yang dilakukan, maka dapat dihitung total keseluruhan dari pernyataan responden yaitu terdiri dari 80 jumlah pernyataan setuju oleh responden dengan jumlah rata-rata persentase $64 \%$, dan 45 jumlah pernyataan sangat setuju dengan jumlah rata-rata persentase $36 \%$ dari 5 jumlah pertanyaan yang ada pada kuisioner, seperti ditunjukkan pada Gambar 17. 


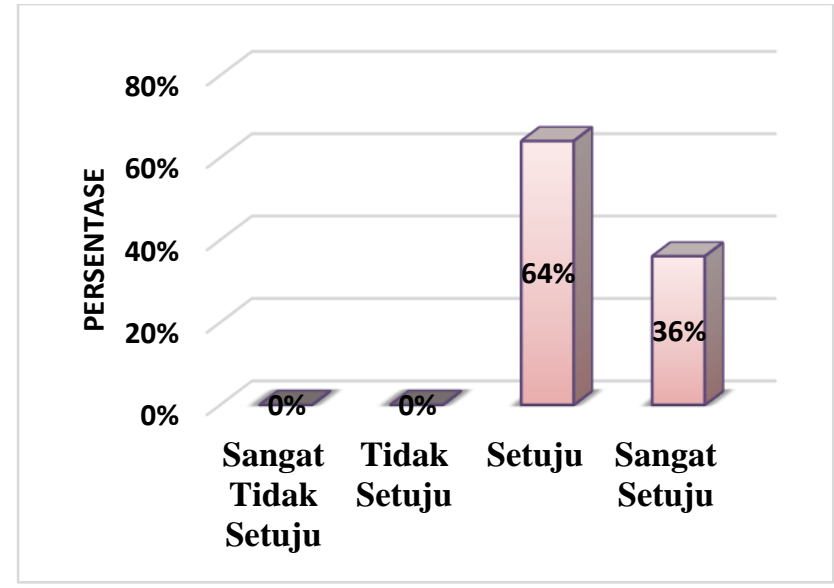

Gambar 17. Grafik hasil rata-rata pernyataan responden

\section{KESIMPULAN DAN SARAN}

\subsection{Kesimpulan}

Berdasarkan hasil penelitian dan pembuatan sistem yang telah dilakukan, maka didapatkan beberapa kesimpulan sebagai berikut :

Berdasarkan hasil penelitian dan pembuatan

sistem yang telah dilakukan, maka didapatkan

beberapa kesimpulan sebagai berikut :

1. Rancang Bangun Sistem Informasi Layanan Elektronik ini mengambil studi kasus pada program studi teknik informatika fakultas teknik universitas mataram dengan pokok permasalahan yaitu, suratmenyurat. Pada sistem ini dibuat pengajuan surat permohonan oleh mahasiswa yang nantinya permohonan surat tersebut akan dikelola oleh admin. Sebelumnya pengajuan surat permohonan ini cara pengisiannya masih manual sekarang dibuat lebih terkomputerisasi agar memudahkan pengguna.

2. Dalam rancang dan bangun sistem layanan elektronik ini mendukung pelayanan suratmenyurat, dilakukan dengan menggunakan 7 (tujuh) tahapan, yaitu studi literatur, pengumpulan data, analisa sistem, desain, implementasi, pengujian dan dokumentasi. Sistem ini dibangun dengan bahasa pemrograman HTML, PHP dan Javascript dengan menggunakan laravel sebagai framework-nya, MySql sebagai server databasenya dan xampp sebagai server local-nya.

3. Hasil pengujian dengan metode black box seluruh fungsi telah sesuai dengan sistem yang diusulkan dan diharapkan oleh pengguna sistem khususnya mahasiswa dan admin.
4. Berdasarkan hasil pengujian metode Mean Opinion Score dapat disimpulkan bahwa sebesar $64 \%$ responden menyatakan setuju dan sebesar $36 \%$ responden menyatakan sangat setuju dengan rancang bangun sistem informasi layanan elektronik program studi teknik informatika fakultas teknik universitas mataram.

\subsection{Saran}

Dikarenakan masih banyak kekurangan dari penulis dalam mengembangkan sistem ini, terdapat beberapa saran untuk dapat membuat sistem ini menjadi lebih baik pada waktu yang akan datang diantaranya :

1. Sistem ini hanya mencakup 5 pengajuan permohonan surat, masih dapat dikembangkan untuk pengajuan permohonan surat lainnya yang ada pada program studi teknik informatika.

2. Sistem layanan surat menyurat ini hanya di peruntukkan pada program studi teknik informatika fakultas teknik universitas mataram, namun sistem ini masih belum bisa di berlakukan pada tempat atau universitas lain karena perbedaan tata cara pelayanan pengajuan permohonan surat.

3. Untuk mengakses pengajuan permohonan surat ini mahasiswa dapat mengajukannya dimana saja, tidak harus saat berada dilingkungan kampus. Hanya saat meminta tanda tangan dan menyerahkan surat ini saja mahasiswa di haruskan untuk ke kampus.

\section{DAfTAR PUStaka}

[1] W. A. Hidayat, "Sistem Kearsipan Surat Masuk Dan Keluar di Kantor Kepala Desa Tridadi Kecamatan Sleman Kabupaten Sleman Berbasis Visual Basic," Cell, vol. 151, no. 4, pp. 1-46, 2014.

[2] Junidar, "Perancangan Sistem Informasi Arsip Surat Menyurat," 2012.

[3] Sumiati, "Rancang Bangun Sistem Informasi Surat Perintah Perjalanan Dinas Pada Sekretariat Daerah Provinsi Berbasis Web," J. Comput. Sci. Informatics Eng., vol. 2, no. 1, pp. 7-16, 2018.

[4] Dedy Fajar Setyawan, "Rancang Bangun Sistem Informasi Surat UIN Sunan Kalijaga Menggunakan Pendekatan Agile Process Dengan Model Extreme Programming," Ranc. Bangun Sist. Inf. Surat UIN Sunan Kalijaga Menggunakan Pendekatan Agil. Process Dengan Model Extrem. Program., 2014.

[5] A. Anisah and K. Kuswaya, "Analisis Dan Perancangan Sistem Informasi Pengolahan Data Pengeluaran, Penggunaan Bahan Dan Hutang Dalam Pelaksanaan 
Proyek Pada Pt Banamba Putratama," Simetris J. Tek. Mesin, Elektro dan Ilmu Komput., vol. 8, no. 2, p. 507, 2017.

[6] E. P. Agustini, S. D. Purnamasari, and M. Ariandi, "Pendahuluan Metode Penelitian Tahap Perencanaan Sistem Tahap analisa sistem Tahap desain sistem Hasildan Pembahasan Hasil Pembahasan A . Perencanaan Sistem," pp. 313-320, 2009.

[7] Y. Astuti, "Pengelolaan Surat Masuk Dan Keluar Di Kantor Kecamatan Piyungan Bantul Daerah Istimewa Yogyakarta," Cell, vol. 151, no. 4, pp. 1-46, 2014.

[8] H. Andriayani, "Pengelolaan Surat Masuk dan Surat Keluar di Kantor Kecamatan Donorojo Kabupaten Pacitan," 2015.

[9] A. Subekti, "Pengelolaan Surat Masuk dan Suran Keluar di Jogjatronik Mall Yogyakarta," 2015.
[10] A. G. Purba, "Prosedur Pengelolaan Surat Masuk dan Surat Keluar pada Bagian Umum Badan Pemberdayaan Usaha Milik Daerah Kabupaten Sragen," Telemat. Informatics, vol. 19, no. 1, pp. 2740, 2014.

[11] B. Adi Pranata, A. Hijriani, and A. Junaidi, "Perancangan Application Programming Interface (Api) Berbasis Web Menggunakan Gaya Arsitektur Representational State Transfer (Rest) Untuk Pengembangan Sistem Informasi Administrasi Pasien Klinik Perawatan Kulit," J. Komputasi, vol. 6, no. 1, pp. 33-42, 2018.

[12] Suendri, "Implementasi Diagram UML (Unified Modelling Language) Pada Perancangan Sistem (Studi Kasus : UIN Sumatera Utara Medan)," J. Ilmu Komput. dan Inform., vol. 3, no. 1, pp. 1-9, 2018. 